\title{
Genetic Diversity Study of Egyptian Barley Cultivars Using Sequence-Related Amplified Polymorphism (SRAP) Analysis for Water Stress Tolerance
}

\author{
Samah Abdeallah Mariey ${ }^{1}$, Mona A.M. El-Mansoury ${ }^{2}$ and Maha A. El-Bialy ${ }^{3}$ \\ Barley Res. Dept., Field Crops Res. Institute, Agricultural Res. Center, Egypt, \\ ${ }^{2}$ Soils, Water and Environment Res. Inst., Agric. Res. Center, Giza, Egypt and ${ }^{3}$ Water \\ Management Res. Inst., National Water Res. Center, Egypt
}

\begin{abstract}
A TWO-YEAR field screening analysis was evaluated to study the analysis of variance, mean performances, principal components analysis (PCA) and similarity levels among 19 Egyptian barley cultivars for six parameters during two consecutive seasons 2013/2014 and $2014 / 2015$ to identify their response to water stress conditions. The results exhibited significant differences among all cultivars for all studied characteristics, and highest mean values for all studied traits have been detected for Giza 2000, Giza 131 and Giza 126, which had positive and highest values of PCA. Also, highest similarity levels were observed among these cultivars with more than $90 \%$. So we could consider that these cultivars as tolerant to water stress. Molecular marker analysis was used as a new molecular marker called sequence-related amplified polymorphism (SRAP) to determine the genetic diversity and relationships among 19 Egyptian barley cultivars for water stress tolerance. Nine selected primer combinations were amplified and gave 71 total fragments, at which primer combination "me5+em1" gave the highest polymorphism (100\%) and the highest polymorphic information content PIC was $(0.97)$. The dendrogram of SRAP markers had clustered all the Egyptian cultivars into four groups; each group includes the most closed cultivars together according to their response to water stress. Results showed that the SRAP marker technique could be efficiently used to assess genetic variation among Egyptian barley genotypes and their ability for tolerance to water stress.
\end{abstract}

Keywords: Hordeum vulgare, Morphological traits, Principal components analysis, Water stress tolerance, SRAP marker, PIC,UPGMA cluster analysis.

\section{Introduction}

Drought stress is one of the most important aggressive factors for plant production in the arid and semi-arid regions of the world, which affects morphological, physiological, biochemical and molecular processes in plants. (Zhao et al., 2008). Amongst the crops barley (Hordeum vulgare L.) is the first important winter cereal crop grown in arid and semi-arid regions in North Africa, because of its earliness, ability to escape terminal drought-stress, and grown in areas where irrigation is poorly available. (Ceccarelli et al., 1987). Barley is also considered as a good model species for cereals due to its commonly accessible genetic information (Hayes et al., 2000). Robinson et al. (2000) reported that the development of abiotic stress tolerance in barley depends mainly on using the available genetic variation in both cultivated barley (H. vulgare L.) and wild barley ( $H$. vulgare subsp. spontaneum). Molecular markers analyses are universally used to study the genetic diversity and the relationships among genotypes and cultivars because the molecular marker technique is powerful tools and independent of environmental effects (Liu et al., 2006). Li and Quiros (2001) described a new DNA-PCR marker system named Sequence Related Amplified Polymorphism (SRAP), based on promoter regions to amplify open reading frames (ORFs) so need designed specified primer combination, which forward primers, specially amplify exon regions and the reverse primers preferentially amplify intron regions. SRAP has been established to be a suitable tool for genetic diversity studies more than other markers because of its simplicity, reproducibility, discloses numerous, co-dominant markers and easy isolation of bands for sequencing (Esposito et al., 2007). SRAP markers have been successfully used to measure the genetic diversity and relationships in many cereal crops such as Maize (Jiang et al., 2007) durum wheat (Zaefizadeh and Goleiv, 
2009), rice (Dai et al., 2012), barley (Yang et al., 2008 \& 2010 and Dizkirici et al., 2010), and in Egyptian barley was used as first time by Mariey et al. (2015). Genetic variability in barley for drought tolerance has been previously studied using different DNA molecular markers such as SSR (Forster et al., 2004) and RAPD (Nazari and Pakniyat, 2008). However, there are not much reports on studying genetic diversity of barley cultivars and/or genotypes using SRAP markers for abiotic stress. Thus, the objective of the present study was to use the SRAP markers as a first report to investigate the genetic diversity of 19 Egyptian barley cultivars for water stress tolerance in order to classify them on the SRAP molecular level and provide genetic information for the future breeding programs for water stress.

\section{Materials and Methods}

Barley cultivars

Nineteen barley cultivars (Hordeum vulgare L.) were used in this study; their names and pedigree are shown in Table 1 were kindly provided by Sakha Barley Research Dept., Field Crops Research Institute, Agricultural Research Center, Egypt.

TABLE 1. Name, and row type and pedigree of 19 barley cultivars used in the field experiment

\begin{tabular}{|c|c|c|c|c|}
\hline No. & Name & \multicolumn{2}{|c|}{ Row type } & Pedigree \\
\hline 1 & Giza 117 & hulled & Six row & Baladi 16/Palestine 10 \\
\hline 2 & Giza 118 & hulled & Six row & Beecher (Introduced from USA) \\
\hline 3 & Giza 119 & hulled & Six row & Baladi16/Gem(G.I. 7243) \\
\hline 4 & Giza 121 & hulled & Six row & Baladi16/Gem. \\
\hline 5 & Giza 123 & hulled & Six row & Giza 117/FAO 86 \\
\hline 6 & Giza 124 & hulled & Six row & Giza 117/Bahteem 52// Giza 118/FAO 86 \\
\hline 7 & Giza 125 & hulled & Six row & Giza117 / Bahteem52// Giza118 /FAO86(sister line to G.124 \\
\hline 8 & Giza 126 & hulled & Six row & Baladi Bahteem/S D729-Por12762-BC. \\
\hline 9 & Giza 127 & hulled & $\begin{array}{l}\text { Two } \\
\text { row }\end{array}$ & W12291/B0gs//Hamal-02 \\
\hline 10 & Giza 128 & hulled & $\begin{array}{l}\text { Two } \\
\text { row }\end{array}$ & W12291/4/11012-2170-22425/3/"Apam"/"B65"//"A16" \\
\hline 11 & Giza 129 & hulless & Six row & Deir Alla 106/Cel//As46/Aths*2” \\
\hline 12 & Giza 130 & hulless & Six row & Comp.cross"229//Bco.Mr./DZ02391/3/Deir Alla 106 \\
\hline 13 & Giza 131 & hulless & Six row & $\begin{array}{l}\text { CM67B/CENTENO//CAMB/3/ROW906.73/4/GLORIABAR/ COME-B/5/ } \\
\text { FALCON BAR/6/LINO }\end{array}$ \\
\hline 14 & Giza 132 & hulled & Six row & Rihane-05//AS 46/Aths*2Athe/ Lignee 686 \\
\hline 15 & Giza 133 & hulled & Six row & ICB91-0343-0AP-0AP-0AP-281AP-0AP \\
\hline 16 & Giza 134 & hulled & Six row & ICB91-0343-0AP-0AP-0AP-289AP-0AP \\
\hline 17 & Giza 135 & hulless & Six row & $\begin{array}{l}\text { ZARZA/BERMEJO/4/DS4931//GLORIABAR/COPAL/3/SEN/5/AYAROS } \\
\text { PLAISANT/7/CLN-B/LIGEE640/3/S.P-B//GLORIAAR/ COME B/5/ }\end{array}$ \\
\hline 18 & Giza 136 & hulless & Six row & $\begin{array}{l}\text { FALCONBAR/6/LINOCLN-B/A/S.P- /LIGNEE640/3/S.P-B//GLORIA- } \\
\text { BAR/COME B/5/FALCONBAR/6/LINO }\end{array}$ \\
\hline 19 & Giza 2000 & hulled & Six row & Giza117/Bahteem52// Giza118/ FAO86 / 3/Baladi16/ Gem \\
\hline
\end{tabular}

Field investigational design

Two separated field experiments were carried out at Sakha Research Farm (North of Egypt), during two growing seasons; 2013/2014 and 2014/2015 under irrigated and non-irrigated water stress conditions using 19 cultivars planted in a randomized complete block design (RCBD) with three replicates; each plot consisted of a cultivar which was planted in six rows of $3.5 \mathrm{~m}$, spread out with $20 \mathrm{~cm}$ among rows (plot area $=4.2 \mathrm{~m}^{2}$ ). The first experiment (normal conditions) was irrigated twice after sowing, first irrigation on 45 days at tillering stage and the second irrigation on 75 days at booting stage, while the second experiment (water stress conditions) was irrigated once just at sowing irrigation.
Soil samples

Soil samples were taken before land preparation in two depths from the soil surface; i.e. 0-15 cm and $15-30 \mathrm{~cm}$. Chemical properties of soil samples from the two isolated field experimental site during the two following seasons, are presented in Table 2. Field experimental samples were analyzed according to Piper (1950) and Black et al. (1965). Water application was monitored via water meter and some climatic characteristics such as maximum and minimum temperature (C), relative humidity $(\mathrm{RH}) \%$, wind speed (WS) $\mathrm{m} /$ sec, rainfall, evapotranspiration (ETo ) during the two seasons at Sakha Station as shown in Table 3 . 
TABLE 2. Chemical properties of soil samples from the Sakha field experiments during the two following seasons

\begin{tabular}{ccc}
\hline Chemical properties & $\mathbf{2 0 1 3 / 2 0 1 4}$ & $\mathbf{2 0 1 4 - 2 0 1 5}$ \\
\hline $\mathrm{pH}$ & 7.10 & 8.00 \\
$\mathrm{EC} \mathrm{dSm}^{-1}$ & 3.00 & 3.70 \\
$\mathrm{CaCO}_{3}$ & 0 & 0 \\
$\mathrm{Ca}^{++}$ & 4.6 & 4.8 \\
$\mathrm{Mg}^{++}$ & 2.5 & 5.9 \\
$\mathrm{Na}^{++}$ & 14.8 & 14.9 \\
$\mathrm{~K}^{+}$ & 0.2 & 0.5 \\
$\mathrm{SO}$ & 18.2 & 7.1 \\
$\mathrm{Cl}$ & 11.2 & 10.3 \\
$\mathrm{HCO}_{3}$ & 5.5 & 5.3 \\
\hline
\end{tabular}

TABLE 3. Mean of some meteorological data for kafr EI -Sheikh area during the two years 2013/2014 and 2014/2015

\begin{tabular}{|c|c|c|c|c|c|c|c|c|c|}
\hline & \multicolumn{9}{|c|}{$2013 / 2014$} \\
\hline \multirow[b]{2}{*}{ Month } & \multicolumn{3}{|c|}{ Temperature $^{\circ}(\mathrm{C})$} & \multicolumn{3}{|c|}{ Relative humidity (\%) } & $W_{\mathrm{s}}$ & \multirow{2}{*}{$\begin{array}{l}\text { Pan Evap. } \\
\mathrm{mm} / \text { day. }\end{array}$} & \multirow{2}{*}{$\begin{array}{c}\text { Rain } \\
\text { mm }\end{array}$} \\
\hline & Max. & Min. & Mean & Max. & Min. & Mean & $\mathrm{m} / \mathrm{sec}$ & & \\
\hline Dec. & 19.64 & 8.51 & 14.06 & 92.07 & 67.61 & 79.84 & 0.61 & 4.15 & 81.9 \\
\hline Jan. & 20.34 & 7.55 & 13.95 & 93.69 & 70.55 & 80.55 & 0.54 & 1.60 & 20.7 \\
\hline Feb. & 20.64 & 8.19 & 14.42 & 91.90 & 67.15 & 79.53 & 0.79 & 2.52 & 16.5 \\
\hline Mar. & 22.94 & 11.71 & 17.33 & 86.10 & 56.80 & 71.45 & 0.96 & 3.14 & 26.2 \\
\hline April. & 27.50 & 15.53 & 21.52 & 81.80 & 49.80 & 65.8 & 1.07 & 4.91 & 20.2 \\
\hline \multicolumn{10}{|c|}{$2014 / 2015$} \\
\hline \multirow[b]{2}{*}{ Month } & \multicolumn{3}{|c|}{ Temperature ${ }^{0}(\mathrm{C})$} & \multicolumn{3}{|c|}{ Relative humidity (\%) } & $W_{s}$ & \multirow{2}{*}{$\begin{array}{l}\text { Pan Evap. } \\
\text { mm/ day. }\end{array}$} & \multirow{2}{*}{$\begin{array}{c}\text { Rain } \\
\mathrm{mm}\end{array}$} \\
\hline & Max. & Min. & Mean & Max. & Min. & Mean & $\mathrm{m} / \mathrm{sec}$ & & \\
\hline Dec. & 22.27 & 9.72 & 16.00 & 88.60 & 63.50 & 76.05 & 0.53 & 1.72 & 5.7 \\
\hline Jan. & 18.79 & 6.46 & 12.63 & 88.10 & 61.10 & 74.60 & 0.82 & 2.70 & 52.55 \\
\hline Feb. & 19.01 & 7.65 & 13.33 & 86.80 & 62.70 & 74.75 & 0.84 & 2.90 & 38.8 \\
\hline Mar. & 22.69 & 11.69 & 17.19 & 82.36 & 58.82 & 70.59 & 1.01 & 3.23 & 15.25 \\
\hline April. & 25.64 & 13.70 & 19.67 & 78.30 & 48.50 & 63.40 & 1.11 & 6.07 & 35.85 \\
\hline \multicolumn{10}{|c|}{ Water application m3. fed-1 } \\
\hline \multicolumn{5}{|c|}{$2013 / 2014$} & \multicolumn{5}{|c|}{$2014 / 2015$} \\
\hline \multirow{2}{*}{$\begin{array}{c}\text { growth } \\
\text { stages of } \\
\text { Irrigation }\end{array}$} & \multicolumn{2}{|c|}{ Irrigation water (IW) } & \multicolumn{2}{|c|}{$\begin{array}{c}\text { Total water amount } \\
\text { (m3) }\end{array}$} & \multicolumn{2}{|c|}{ Irrigation water (IW) } & \multicolumn{3}{|c|}{ Total water amount(m3) } \\
\hline & irrigated & stress & irrigated & stress & irrigated & stress & irrig & & ess \\
\hline Sowing & 500 & 500 & \multirow{3}{*}{13330} & \multirow{3}{*}{500} & 400 & 400 & \multirow{3}{*}{\multicolumn{2}{|c|}{1060}} & \multirow{3}{*}{400} \\
\hline Tillering & 380 & 0 & & & 280 & 0 & & & \\
\hline Booting & 540 & 0 & & & 450 & 0 & & & \\
\hline
\end{tabular}

Source: Meteorological Station at Sakha Agricultural Research Station $31^{\circ}-07 \mathrm{~N}$ latitude, $30^{\circ}-57 \mathrm{E}$ longitude with an elevation of about 6 meters a above mean sea level

\section{Studied traits}

Six growth traits for the 19 barley cultivars were measured in this investigation including, days to $50 \%$ heading, plant height $(\mathrm{cm})$, No. grains spike ${ }^{-1}$, No. spikes $\mathrm{m}^{-2}(\mathrm{~cm})$, grain yield $(\mathrm{t}$ $\mathrm{h}^{-1}$ ) and harvest index $\%$.

\section{Statistical analysis}

Collected data from the two seasons were statistically analyzed as a randomized complete block design (RCBD) using analysis of variance (ANOVA) for each season two location, two seasons, over all the two field experimental and over all the two seasons 2013/2014 and 2014/015 as a combined analysis. All statistical analyses were performed using the computer software MSTAT-C Computer Program according to
(Snedecor and Cochran, 1969). Stress intensity $(\mathrm{SI})=1-(\mathrm{G} \hat{Y} \mathrm{~s} / \mathrm{G} \hat{\mathrm{Y} p})$, whereas $\mathrm{G} \hat{Y} \mathrm{~s}$ and $\mathrm{G} \hat{\mathrm{Y} p}$ are the means of all genotypes under stress and normal conditions, respectively, according to (Munns and James, 2003). Principal component and cluster analysis were analyzed using a computer software program Minitab v.12.

\section{DNA extraction and PCR amplification}

Genomic DNA was isolated from the 19 barley cultivars fresh leaves using CTAB method according to Doyle and Doyle (1990), using nine SRAP primer combinations; their names and sequences are shown in Table 4. PCR cycling was carried out as the following program; initial denaturation at $94^{\circ} \mathrm{C}$ for $4 \mathrm{~min}$, followed by five cycles comprising 1 -min denaturation at $94^{\circ} \mathrm{C}$, 1-min annealing at $35^{\circ} \mathrm{C}$, and $30 \mathrm{~s}$ of elongation 
TABLE 4. SRAP Primers combinations name and sequences

\begin{tabular}{|c|c|c|}
\hline Name & Forward primer sequences & Reverse primer sequences \\
\hline me1+em1 & TGAGTCCAAACCGGATA & GACTGCGTACGAATTAAT \\
\hline me1+em2 & TGAGTCCAAACCGGATA & GACTGCGTACGAATTTGC \\
\hline me1+em3 & TGAGTCCAAACCGGATA & GACTGCGTACGAATTGAC \\
\hline me2+em1 & TGAGTCCAAACCGGAGC & GACTGCGTACGAATTAAT \\
\hline me2+em2 & TGAGTCCAAACCGGAGC & GACTGCGTACGAATTTGC \\
\hline me2+em3 & TGAGTCCAAACCGGAGC & GACTGCGTACGAATTGAC \\
\hline me5+em1 & GAGTCCAAACCGGAAG & GACTGCGTACGAATTAAT \\
\hline me5+em2 & GAGTCCAAACCGGAAG & GACTGCGTACGAATTTGC \\
\hline me5+em3 & GAGTCCAAACCGGAAG & GACTGCGTACGAATTGAC \\
\hline
\end{tabular}

at $72^{\circ} \mathrm{C}$. In the following 30 cycles, denaturation at $94^{\circ} \mathrm{C}$ for $1 \mathrm{~min}$, annealing at $50^{\circ} \mathrm{C}$ for $1 \mathrm{~min}$, and elongation at $72^{\circ} \mathrm{C}$ for $30 \mathrm{~s}$ were carried out, ending with an elongation step for $10 \mathrm{~min}$ at $72^{\circ}$ $\mathrm{C}$. The amplified products were stored at $4^{\circ} \mathrm{C}$. The PCR products were separated by electrophoresis using 2\% agarose gel in $1 \mathrm{x}$ TBE buffer against $100 \mathrm{bp}$ DNA Ladder as a size marker. Bands were detected with ethidium bromide staining and visualized under UV light, then photographed on Gel Documentation.

\section{SRAP markers data analysis}

The amplified bands from SRAP were scored as a binary data under the heading of total scorable fragments, which was determined for each cultivar. The data were used to estimate the genetic similarity on the basis of number of shared amplification products (Nei and Li, 1979). Polymorphism Information Content (PIC) values were done to distinguish between cultivars for each primer according to (Anderson et al., 1993). Cluster analysis was performed to produce a denderogram using unweighted pair-group method with arithmetical average (UPGMA) based on Jukes-Cantor coefficient using PAST program adapted by Hammer et al. (2001).

\section{Results and Discussion}

\section{Field experimental analysis}

Field screening analysis is remaining the main tools to identify the response of cultivars to water stress conditions, in spite of its limitation of time required and environmental addiction. The variance analysis, mean performance, stress intensity, PCA analysis and the cluster similarity for the six studied traits were calculated in this study to evaluate the 19 Egyptian barley cultivars tolerance to water stress under irrigated and non-irrigated condition during the two cropping seasons 2013/014 and 2014/015.

\section{Days to heading (DH)}

Regarding days to heading (DH), data in Table 5 showed high significant differences among all barley cultivars for $\mathrm{DH}$ in the two seasons, and significant difference interaction between the two seasons (S) and the cultivars (C) were found, while the data clearly showed that there were no significant interaction between the two treatments $(\mathrm{T})$ and cultivars $(\mathrm{C})$. These results are in agreement with (Haddadin, 2015). Results in Table 6 showed the mean performance of $\mathrm{DH}$ for the 19 cultivars during the two growing seasons; in the first season, the results indicated that Giza 123 was the earliest under both irrigated, non- irrigated conditions and their combined with values of $(89.7,88.3$ and 89.0 days), respectively. However, Giza 129 was the latest barley cultivar under irrigated and non-irrigated conditions and their combined, which recorded (104.0, 97.7and100.8 days), respectively. In the second season, the earliest cultivar under irrigated, non-irrigated conditions and their combined was Giza 131 with values of (91.7, 90.7 and 91.2days), respectively. The reduction of $\mathrm{DH}$ in normal and water deficit conditions was $4 \%$ in the first season and $3.3 \%$ in the second season, and the stress reduced all=cultivars for HD indicting that the earlier heading in barley is the better adapted to low reainfed areas, whereas the earliness probably is the most efficient drought escape mechanism. These results were consistent with those of El- Seidy (1997), Shakhareh et al. (2001), El-Madidi et al. (2005) and Abu-El-Lail et al. (2016). The stress intensity (SI) was equal to $3.99 \%$ in the first season and $3.38 \%$ in the second season indicating that $\mathrm{DH}$ trait proficient a minor water stress in the study. For coefficient of variation, genotypic yields under irrigated conditions revealed greater variation than the non-irrigated conditions $(\mathrm{CV} \%=1.14$ vs. $0.79 \%)$ in first season but in second season $\mathrm{CV}$ variation under normal was smaller than variation under the stress environment $(\mathrm{CV} \%=0.7$ vs. $1.3 \%$ ). These results were in agreement with (Singh, 2011 and Chalak et al., 2015), who reported that days to heading had small C.V. at which this trait is a stable.

\section{Plant height cm (PH)}

Plant height is affected by agronomic factors and other treatments, based on the results from the variance analysis data in Table 5 that showed that 

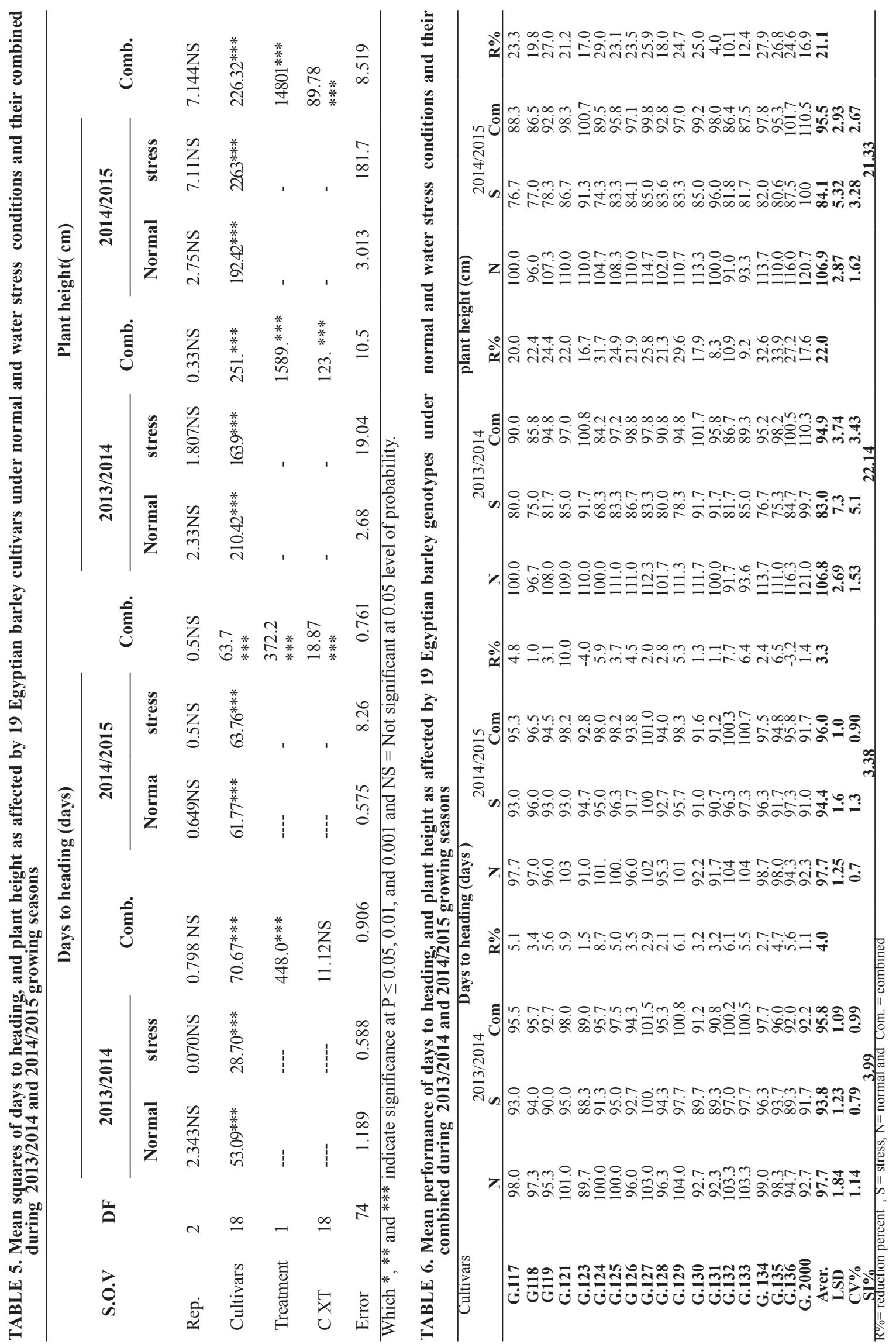

J. Sus. Agric .Sci. 44, No.1 (2018) 


\section{Number of grains per spike}

Concerning number of grains spike ${ }^{-1}$, data in Table 7 showed high significant differences among all cultivars, and high significant interaction were found between cultivars and treatments as well as between cultivars and seasons. The results of mean performance as shown in Table 8, revealed that barley cultivar Giza 136 ranked first in terms of number of grains spike ${ }^{-1}$ under both conditions (irrigated and non-irrigated) and their combined during the two growing seasons, while, Giza 127 (two-wowed barley) and Giza 119 (sixwowed barley) both had the lowest number for grains spike ${ }^{-1}$ under irrigated and non-irrigated conditions and in their combined, during the two growing seasons. The reduction of this trait under normal and water stress conditions was $12 \%$ in the first season and $11.1 \%$ in the second season. In addition, the data showed reductions in this trait among all the cultivars under water stress condition expect for Giza 136 in the first season and Giza 135 in the second season both had no reduction between normal and stress conditions. Stress intensity (SI) was $11.89 \%$ in the first season and $11.04 \%$ in the second season. The results of the coefficient of variation showed that the genotypic yield under irrigated conditions was smaller than variation on non-irrigated conditions in both growing seasons. The present results were in agreement with Rizza et al. (2004), Haddadin et al. (2013) and Haddadin (2015) who confirmed that the reduction in No. of grains spike ${ }^{-1}$ under water stress treatments could be due to the reduction in grain yield components, whereas this trait was more sensitive to water stress.

\section{Number of spikes per square meter}

Data in Table 7 showed high significant differences among all barley cultivars during the two 2012/13 and 2013/14 growing seasons and highly significant interaction between cultivars and treatments as well as between cultivars and seasons across their combined analysis was observed. For mean performances as shown in Table 8, data indicated that the Giza 2000 had the highest number of spikes $\mathrm{m}^{-2}$ under irrigated, non-irrigated and their combined conditions during both growing seasons with reduction of $3.2 \%$ in the first season and $2.9 \%$ in the second season, while the lowest number of spike $\mathrm{m}^{-2}$ was showed by Giza 119 under irrigated and nonirrigated conditions and their combined during two growing seasons. The average reduction of this trait under normal and water stress conditions was $31.4 \%$ in the first season and
$26.4 \%$ in the second season. Our results are in a good harmony with those reported by Hamam and Salman (2007) and Abu-El-Lail et al. (2016) who reported that the water stress decreased all cultivars under non- irrigated conditions, paralleled with irrigated conditions indicating that this trait of number of spikes $\mathrm{m}^{-2}$ was the most sensitive to water stress, also Sanchez et al. (2002) and Samarah (2005) reported that the reduction in that trait under water stress was due to the increase in the number of sterile spikes and the decrease in the number of fertile spikes in barley.

\section{Grain yield $\left(t h^{-1}\right)$}

Data in Table 9 showed a high and a significant difference among all cultivars and between their interactions were found between cultivars and treatments as well as between cultivars and seasons Regarding mean performances, data in Table 10 showed that Giza 2000 had the maximum values under normal, stress and their combined conditions during the two growing seasons. On the other hand, Giza 119 had the minimum values under normal, stress and their combined conditions in both growing seasons with yield reduction of $29.0 \%$ in the first seasons and $23.8 \%$ in the second season, while the yield reductions among cultivars ranged from $18.5 \%$ for Giza 126 to $64.1 \%$ grain yield reduction for Giza 117 in the first season, while for the second season the yield reduction among cultivars ranged from $18.1 \%$ for Giza 126 to $61.7 \%$ for Giza 117 . In addition, the average reduction for grain yield under normal and water stress conditions was $37 \%$ in the first season with stress intensity (SI) of $38.64 \%$, and in the second season the reduction was $41.1 \%$ with stress intensity of (SI) $42.70 \%$ in the second season. Samarah (2005) reported that the grain yield is the component of the three factors: No. spikes $\mathrm{m}^{-2}$, No. grains spike ${ }^{-1}$ and thousand kernel weight, so many factors such as moisture levels can be effective in improving the quality and quantity of grain. Therefore, the reduction in total grain yield under the water stress treatment could be due to the reduction in grain yield components. The coefficient of variation for this trait revealed that the genotypic yields under irrigated conditions were greater than the non-irrigated conditions in both growing seasons. Our results are in line with those reported by Samarah et al. (2009), Haddadin (2015), Fatemeh Sefatgol \& Hamidreza Ganjali (2017) and Singh et al. (2017). 

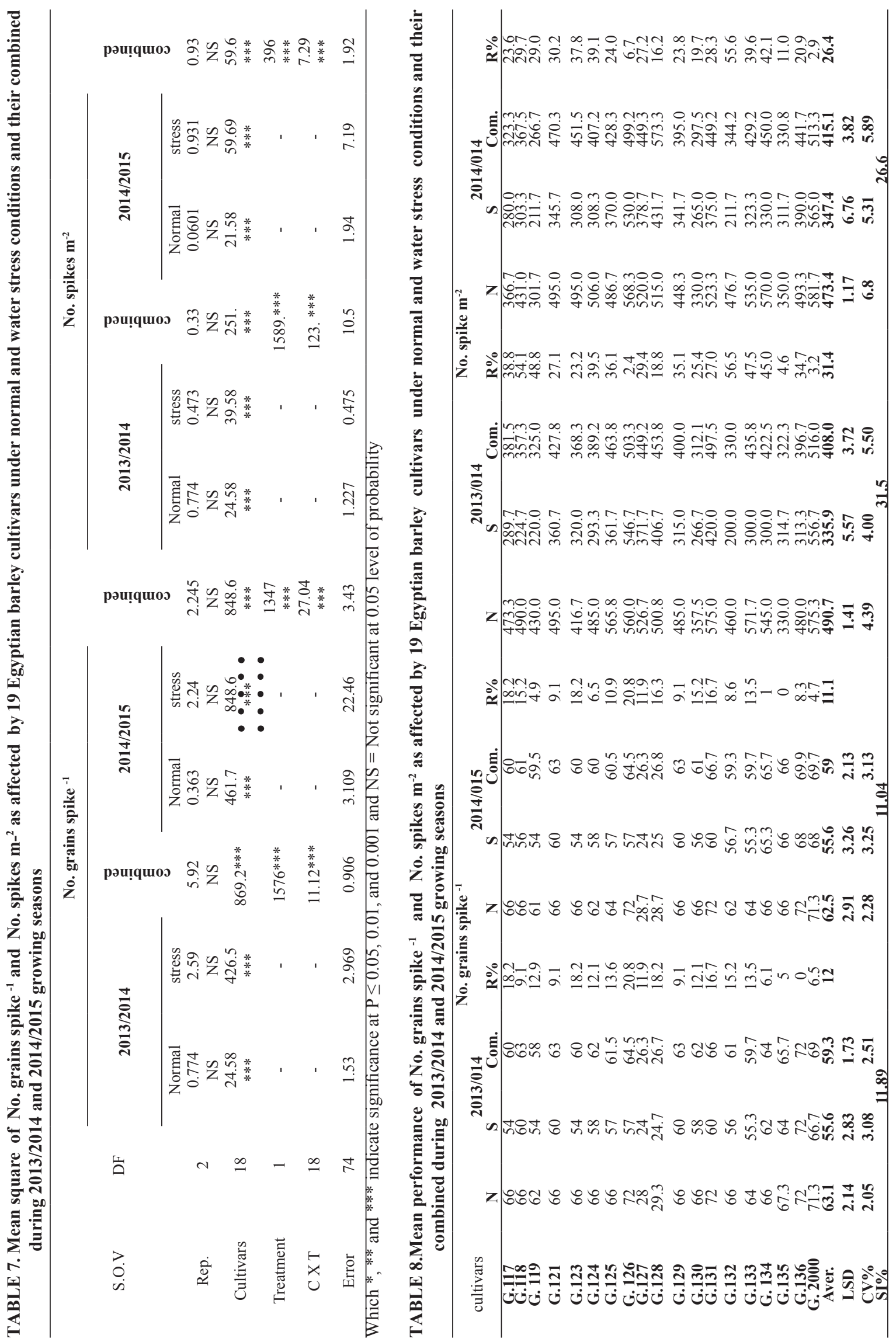

J. Sus. Agric .Sci. 44, No.1 (2018) 

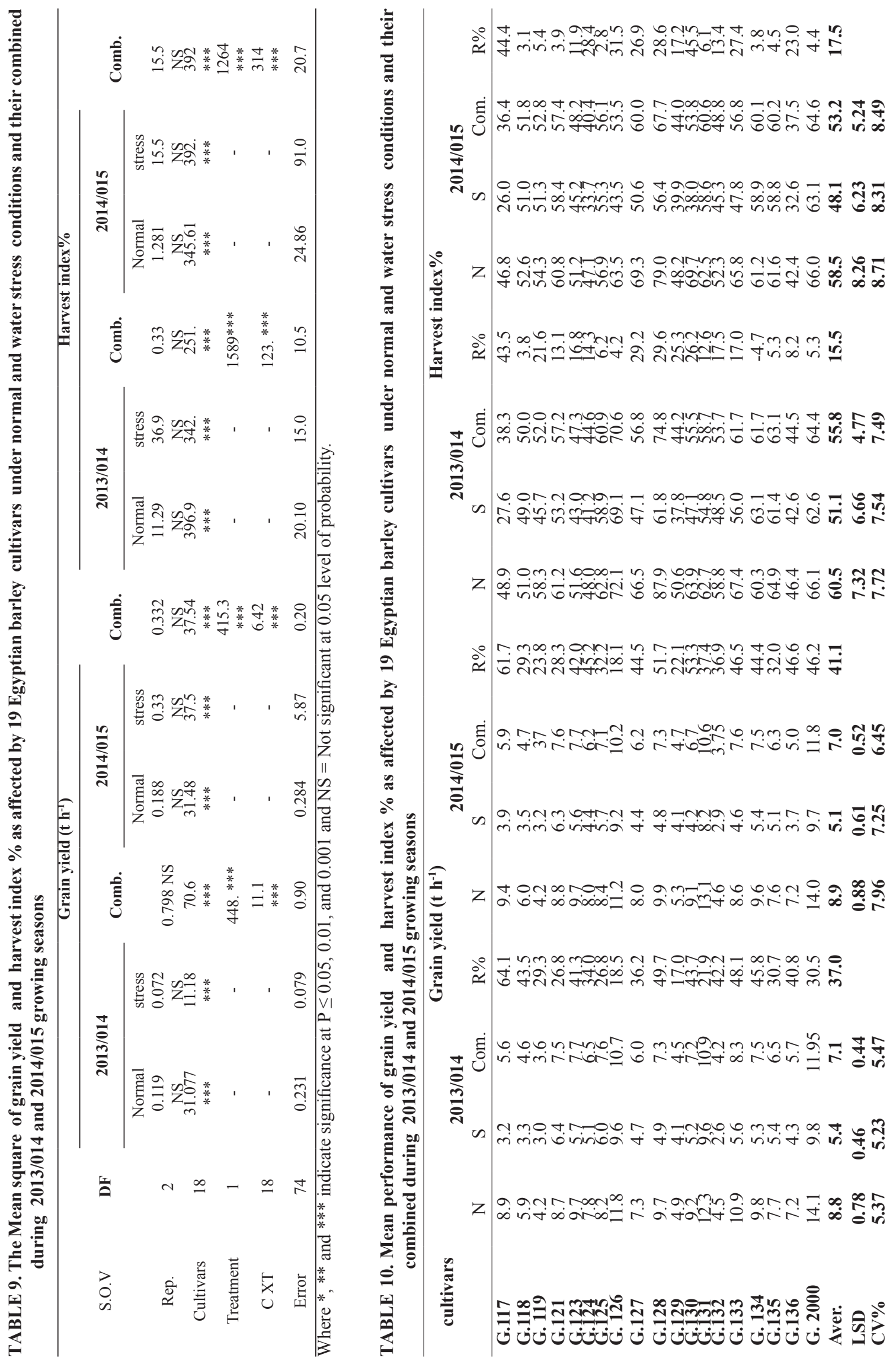

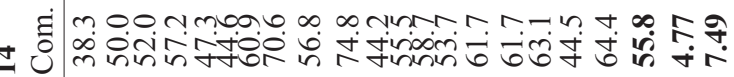

ฝิ

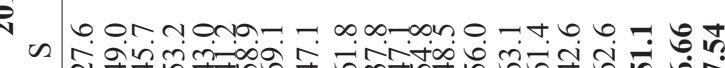

z

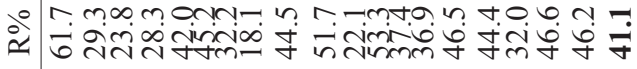

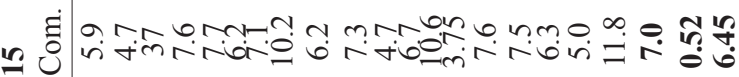

章

य

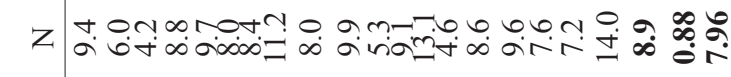

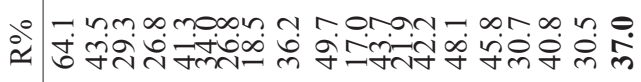

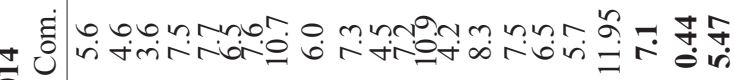

突

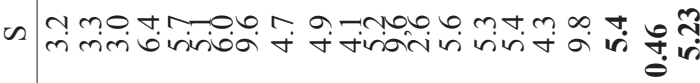

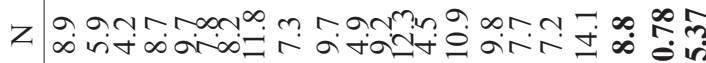

$\stackrel{n=0}{E}$

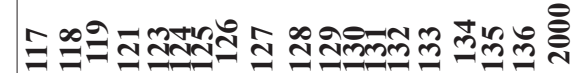

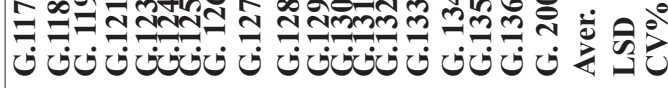

J. Sus. Agric .Sci. 44, No.1 (2018) 


\section{Harvest index (HI)}

Data in Table 9 showed significant and high significant differences among all barley cultivars for $\mathrm{HI}$, also there was a high significant difference found for the interaction between the cultivars and treatments (CxT) and also between them and seasons $(\mathrm{CxS})$. Mean values of harvest index shown in (Table 10) indicated that Giza 128 had the highest (HI) in the first season $(87.9 \%)$ and in the second season $(72.9 \%)$ under normal condition, in addition to Giza 126 that had the highest (HI) in the first season under stress and their combined as well as Giza 2000 that had the highest $\mathrm{HI}$ in the second season under stress and their combined. The reduction of HI under normal and water stress conditions was $15.5 \%$ with $15.54 \%$ stress intensity in the first season and in the second season was $17.5 \%$ with $17.18 \%$ stress intensity as shown in (Table 10). The CV\% of this trait revealed that the variation of genotypic yields under irrigated conditions was greater than the non-irrigated conditions in both growing seasons, whereas, Ranjbar and Cheraghi (2010) reported that harvest index affects the vegetative production and grain yield.: these results were in a good harmony with Samarah et al. (2009), Haddadin (2015), and Fatemeh Sefatgol and Hamidreza Ganjali (2017).

\section{Principal component analysis (PCA)}

Principal component analysis (PCA) based on six agro-morphological traits were used to distinguish all cultivars into groups, where the selection of cultivars could be based on the values of both first and second principal component analysis illustrated in (Table 11) that the first and second principal components analysis (PCA1 and PCA2) covered about $97.1 \%$ of the total variation, where the first PCA1 axis, showed $48.57 \%$ of the total variation influenced by plant height, no. spikes $\mathrm{m}^{-2}$ and grain yield and the second PCA2 axis represents $26.7 \%$ of the total variability due to heading data, no. grains spike ${ }^{-1}$ and harvest index.

Tolerant and moderately tolerant cultivars to water stress could be defined according to the values of PCA1, in which the cultivars that were positive and get high values of PCA1 could be more tolerant and suitable for both irrigated and non-irrigated conditions cultivars such as (Giza 131, Giza 126, and Giza 2000), therefore, we could name PCA1 water stress tolerance components, while the cultivars which was positive in PCA1 and their values were less than one could be known as a moderately tolerant cultivars, therefore, the cultivars (Giza 121, Giza 123, Giza 125, Giza 127, Giza 128, Giza 130, Giza133, Giza 134 and Giza 136) could be used as good moderately tolerant cultivars under water stress conditions. According to PCA2 values we could define the sensitive and moderately sensitive cultivars, which PCA2 known as a stress sensitive component, therefore, the cultivars which were positive in PCA2 and their values more than one could be considered as sensitive cultivars such as (Giza 119 and Giza 132), which were not suitable for both irrigated conditions, in addition, the cultivars which were positive with PCA2 and had values less than one could be considered as moderately sensitive cultivars like (Giza 129, Giza 117, Giza 118 and Giza 124) and will be more suitable for nonirrigated conditions than irrigated stress. These results were in agreement with those reported by Mariey and Khder (2017).

Hierarchical cluster and bi-plot diagram analysis

Results of cluster analysis shown in Table 12 indicated the similarity levels among all cultivars according to their morphological study; the highest similarity level was recorded between two cultivars Giza 118 and Giza 132 equaled 98.16 followed by two cultivars Giza 130 and Giza 135 with 95.4 and between Giza 133 and Giza 134 recorded 95.39 similarity level, while the lowest similarity levels was obtained between Giza 117 and Giza 132. It was=notable that cluster analysis measured a valuable tool for dividing number of cultivars in groups including similarity and dis-similarity cultivars, which would help the breeder to design an effective breeding program. These results were very consistent with those reported by Subhani et al. (2015) and Dorostkar et al. (2016).

Graphical dendrogram resulted from both bi-plot analysis, based on the six studied morphological traits; the values of PCA1 and PCA2 were demonstrated in Fig. $1 \mathrm{~A}$ and cluster analysis which based on similarity levels of traits is showed in Fig. $1 \mathrm{~A}$, where both analyses had divided all cultivars into four groups named A, B, C and D, at which each group included closely related cultivar to other cultivar. A group included the tolerant cultivars which had best morphological performance for all studied traits and had high yield under normal irrigation and water stress conditions, and the similarity levels among them was more than 90.0 such as (Giza 126, Giza 2000 and Giza 131). On the other hand, the cultivars which were placed on $\mathrm{D}$ region had the lowest yield in both conditions and also the highest similarity J. Sus. Agric .Sci. 44, No.1 (2018) 
level was recorded between two cultivars Giza 118 and Giza 132 equaled 98.16 considered as sensitive cultivars such as (Giza 118 and Giza 132), whereas the B region included the moderately tolerant cultivars which had the best grain yield under irrigation conditions such as (Giza 127, Giza128, Giza 133, Giza 121, Giza 134, Giza 135, Giza 125), while C group composed of cultivars which had poor grain yield and lower mean performance and could be considered as moderately sensitive such as (Giza 129, Giza 117, Giza 119 and Giza 124) Consequently, these results were in agreement with similar trends in multivariate analysis of drought tolerance in many crops such as maize (Farshadfar \& Sutka, 2003; durum wheat, Golabadi et al., 2012; and in barley Sharafi et al., 2014 and Mariey \& Khder, 2017 ).

From the abovementioned results, it could be concluded that cluster analysis and bi-plot analysis are considered as a valuable tool based on similarity levels of the agro-morphological traits to subdivide the cultivars into groups including similarity and dissimilarity cultivars, which would help the breeder to plan an effective breeding program, through producing good results if they are crossed with them.

\section{Molecular marker analysis \\ Sequence related amplified polymorphism (SRAP) analysis}

Molecular markers have been revealed to be a very powerful tool for genotype description and estimation of genetic diversity. SRAP marker is becoming the marker of choice for classification and genetic diversity studies in a wide range of plants, therefore this is the first application of SRAP markers as a tool for estimating the level of genetic diversity and classification of 19 Egyptian barley cultivars for water stress tolerance, where a total of 71 fragments were amplified with nine selected primer combinations. The number of bands amplified by each pair of primers ranged from 6 to 10 , with the molecular size between 100 to $1.300 \mathrm{bp}$. Results in Table 13 showed the average percentage of polymorphic loci for all primer combinations was $70.93 \%$ and the average band number amplified from each pair of primers was $7.88 \%$ bands, of which included $5.77 \%$ polymorphic bands, at which the maximum band number among the nine primers combinations was ten obtained by the two primer combination me $5+\mathrm{em} 1$, which gave the highest polymorphism (100\%) (Fig. 2 A), and primer me $5+\mathrm{em} 2$ gave (90\%) (Fig. 2 B). However, primer me1+em 3 had the minimum bands was six with $(66.67 \%)$ polymorphism (Fig. 2 D). The amplified fragments ranged from 70bp to $1300 \mathrm{bp}$ as shown in Fig. 3 (A, $\mathrm{B}, \mathrm{C} \& \mathrm{D})$, the primer me $5+\mathrm{em} 2$ had specific bands found in tolerant cultivars with size 950 bp (Fig. 2 A). Polymorphic information content (PIC) values, which were used to measure the genetic diversity varied from 0.50 to 0.97 , the highest (PIC), related to primer combination me5+em1 was (0.97) indicating that this primer combination is highly informative and might be a useful tool to determine the genetic differences among barley cultivars.

Genetic diversity analysis

Cluster analysis shaped a dendrogram among the 19 Egyptian barley cultivars based on nine SRAP fragments using Jaccard's genetic similarity coefficient, which was outlined by the Unweighted Pair-Group Method (UPGMA), the dendrogram showed that the 19 cultivars were classified into four major clusters, first (T) group included six tolerant cultivars, (i.e. Giza123, Giza125, Giza126, Giza130, Giza131and Giza2000), (MT) group included moderately tolerant cultivars, (MS) group included moderately sensitive cultivars and (S) sensitive cultivars group as shown in Fig. 3A. The PCA based on SRAP fragments also had divided the 19 Egyptian barley cultivars using the percentages of variance of PCA1 (43.9\%) and PCA2 (13.9\%) into four separate groups, namely group A comprised the T cultivars, group B consisted of MT cultivars , Group C included MS cultivars and group D included S cultivars (Fig. $3 \mathrm{~B}$ ). The results of PCA were consistent with those obtained by the UPGMA cluster analysis. The genetic similarity coefficient (GSC) ranged from low similarity (0.57) between Giza133 and Giza121, which proposes that these were the least-related cultivars to highest similarity $(0.93)$ between Giza 2000 and both of Giza 126, Giza 131 and Giza 123 indicating that it was a very close relationship among these cultivars as shown in Table 14, where these cultivars were tolerant to water stress according to our pervious results.

\section{Molecular and morphological analysis}

The Cluster analysis among the 19 Egyptian barley cultivars based on genetic distance and agro-morphological parameters using 
TABLE 11. Principal component analysis for agro- morphological traits of 19 barley cultivars during two seasons

\begin{tabular}{|c|c|c|c|c|c|}
\hline Traits & Axis 1 & Axis 2 & Axis 3 & Axis 4 & Axis 5 \\
\hline Heading data (day) HD & 0.42 & 0.25 & 0.23 & 0.82 & 0.20 \\
\hline Plant height (cm) PH & -0.45 & 0.06 & -0.74 & 0.36 & 0.17 \\
\hline No grains spike $^{-1}$ (g) K/SP & -0.22 & -0.65 & 0.22 & 0.37 & -0.55 \\
\hline No spikes $\mathbf{m}^{-2} \mathrm{SP} / \mathrm{M}$ & -0.48 & -0.1 & 0.53 & -0.04 & 0.62 \\
\hline Grain yield( th- $\left.{ }^{1}\right)$ GR & -0.53 & 0.21 & 0.13 & 0.26 & -0.11 \\
\hline Harvest index ( \%) HI & -0.23 & 0.67 & 0.23 & -0.07 & -0.49 \\
\hline $\begin{array}{l}\text { Genotypes } \\
\text { Giza117 }\end{array}$ & -1.49 & 0.58 & -0.30 & -0.27 & -0.63 \\
\hline Giza118 & -2.05 & 0.14 & -0.33 & -0.81 & 0.08 \\
\hline Giza 119 & -1.45 & 1.68 & -1.16 & -0.05 & 0.85 \\
\hline Giza 121 & 0.54 & -0.26 & 0.82 & 0.20 & 0.16 \\
\hline Giza 123 & 0.57 & -1.16 & -0.73 & 0.66 & -0.39 \\
\hline Giza 124 & -2.11 & 1.65 & 0.04 & -0.34 & -0.69 \\
\hline Giza 125 & 0.27 & -0.37 & 0.58 & 0.08 & 0.33 \\
\hline Giza 126 & 1.88 & -0.40 & 0.38 & -0.29 & -0.63 \\
\hline Giza 127 & 0.12 & -0.99 & 0.01 & 1.78 & -0.33 \\
\hline Giza 128 & 0.97 & -0.97 & -1.65 & -0.49 & -0.08 \\
\hline Giza 129 & -2.23 & 0.98 & 0.50 & 1.05 & 0.43 \\
\hline Giza 130 & 0.76 & -0.36 & -1.12 & 0.17 & 0.35 \\
\hline Giza 131 & 2.45 & -0.67 & -0.21 & -0.95 & -0.54 \\
\hline Giza 132 & -2.29 & 0.89 & 0.64 & -0.37 & 0.05 \\
\hline Giza 133 & 0.36 & -0.52 & 1.28 & -0.87 & -0.24 \\
\hline Giza 134 & 0.59 & -0.32 & 0.73 & -0.21 & 0.52 \\
\hline Giza 135 & 0.11 & -0.02 & 0.06 & -0.73 & 0.79 \\
\hline Giza 136 & 0.29 & -1.88 & -0.07 & 1.00 & -0.46 \\
\hline Giza 2000 & 4.08 & -0.85 & 0.54 & 0.45 & 0.44 \\
\hline Eigenvalue & 2.91 & 1.60 & 0.58 & 0.53 & 0.24 \\
\hline Variance\% & 48.57 & 26.68 & 9.62 & 8.82 & 4.04 \\
\hline Cumulative variance $(\%)$ & 48.6 & 75.2 & 84.8 & 93.7 & 97.7 \\
\hline
\end{tabular}

TABLE 12. Cluster analysis to classify 19 barley cultivars based on agro-morphological traits

\begin{tabular}{cccccc}
\hline No. of clusters & Similarity level & \multicolumn{2}{c}{ Clusters jointed } & New cluster & $\begin{array}{c}\text { No. of entries in } \\
\text { new cluster }\end{array}$ \\
\hline 18 & 98.16 & G118 & G132 & 2 & 2 \\
17 & 95.4 & G130 & G135 & 12 & 2 \\
16 & 95.39 & G133 & G134 & 15 & 2 \\
15 & 94.94 & G119 & G129 & 3 & 2 \\
14 & 93.84 & G125 & G133 & 7 & 3 \\
13 & 93.67 & G123 & G126 & 5 & 2 \\
12 & 93.51 & G131 & G2000 & 13 & 2 \\
11 & 93.21 & G117 & G118 & 1 & 3 \\
10 & 91.80 & G121 & G125 & 4 & 4 \\
9 & 91.74 & G126 & G131 & 8 & 3 \\
8 & 90.72 & G125 & G130 & 5 & 4 \\
7 & 88.32 & G127 & G128 & 9 & 2 \\
6 & 86.76 & G119 & G124 & 3 & 3 \\
5 & 86.60 & G121 & G123 & 4 & 8 \\
4 & 76.45 & G121 & G127 & 4 & 10 \\
3 & 76.40 & G121 & G119 & 1 & 6 \\
2 & 64.67 & G121 & G126 & 4 & 13 \\
1 & 45.40 & G117 & G121 & 1 & 19 \\
\hline
\end{tabular}


Jacquard's genetic similarity coefficient was outlined by the UPGMA cluster analysis, the diagram divided the 19 cultivars into two main groups; each group is divided into two sub-groups as shown in Fig 4. The first main cluster included two sub-cluster one include the $\mathrm{T}$ cultivars and the other included the MT cultivars, while the second main cluster for sub-group included sensitive cultivars and other one had the MS cultivars together. Genetic diversity analysis is necessary in plant breeding; SRAP is a suitable molecular marker system for genetic diversity analysis in plants. Since SRAP has many features such as ease, dependability, flexibility, detection of multiple loci and cost-effectiveness, which allows beginners and experienced people to achieve SRAP routinely with incomplete facilities or in well-established genomics labs. As genome sequence information is not necessary for SRAP detection, SRAP can be used to perform genetic diversity analysis in a wide range of living organisms. (Li et al., 2013). In this study, seventy one alleles were amplified by nine primer combinations for water stress were higher in fragment number than that given in the genetic diversity on the barley using other DNA markers such as SSR markers (Forster et al. 2004), RAPD (Nazari and Pakniyat, 2008). The results of the present study showed that there were high genetic differences among Egyptian barley cultivars for water stress condition based on the agr-morphological traits which confirmed by SRAP markers. Thus, these genetic differences among Egyptian barley cultivars using SRAP marker could be more efficiently to assess genetic variation among them and their ability for tolerance for water stress breeding programs to product suitable cultivars at normal and water stress conditions.

\section{Acknowledgement}

We would like to thank all staff of Plant Genetics Lab., Institute of Genetic Resources, Fac., of Agri., Kyushu Univ., Japan for their support and help to do the molecular part in their lab.

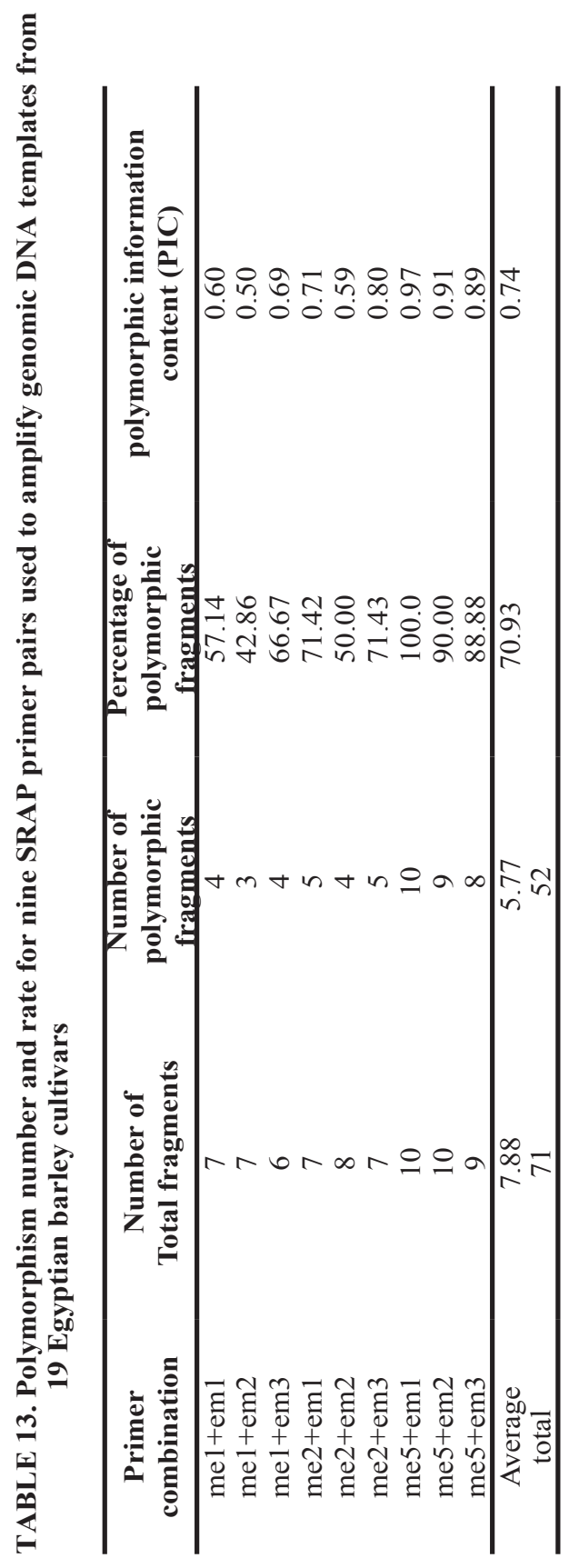



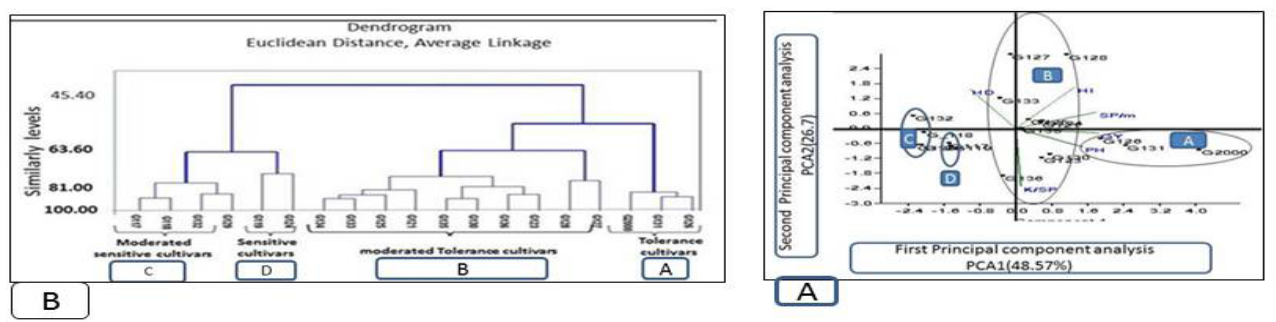

Fig.1. Cluster analysis and biplot analysis based on agro- morphological traits for 19 Egyptian barley cultivars

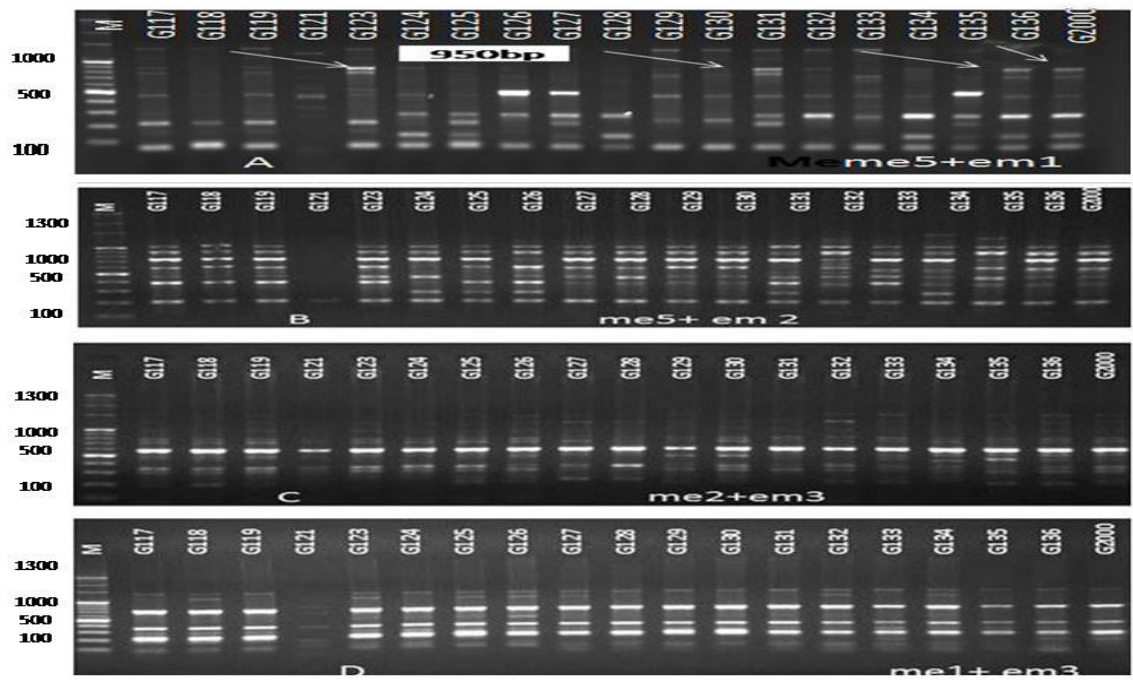

Fig. 2. Amplification results of the primers combination (A) me5+em1, (B) me 5+ em2,(C) me2+em3 and (D) me1+em3 in 19 Egyptian barley cultivars
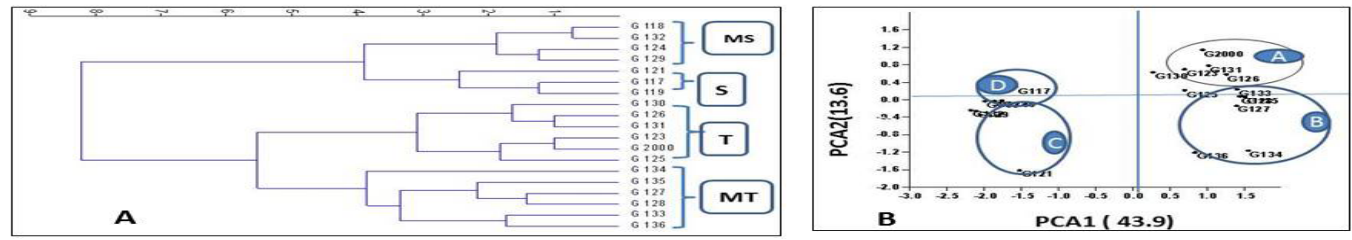

Fig. 3. Dendrogam and the principal component analysis among 19 Egyptian barley cultivars from cluster analysis (UPGMA) based on genetic similarity estimates from the SRAP marker analysis 

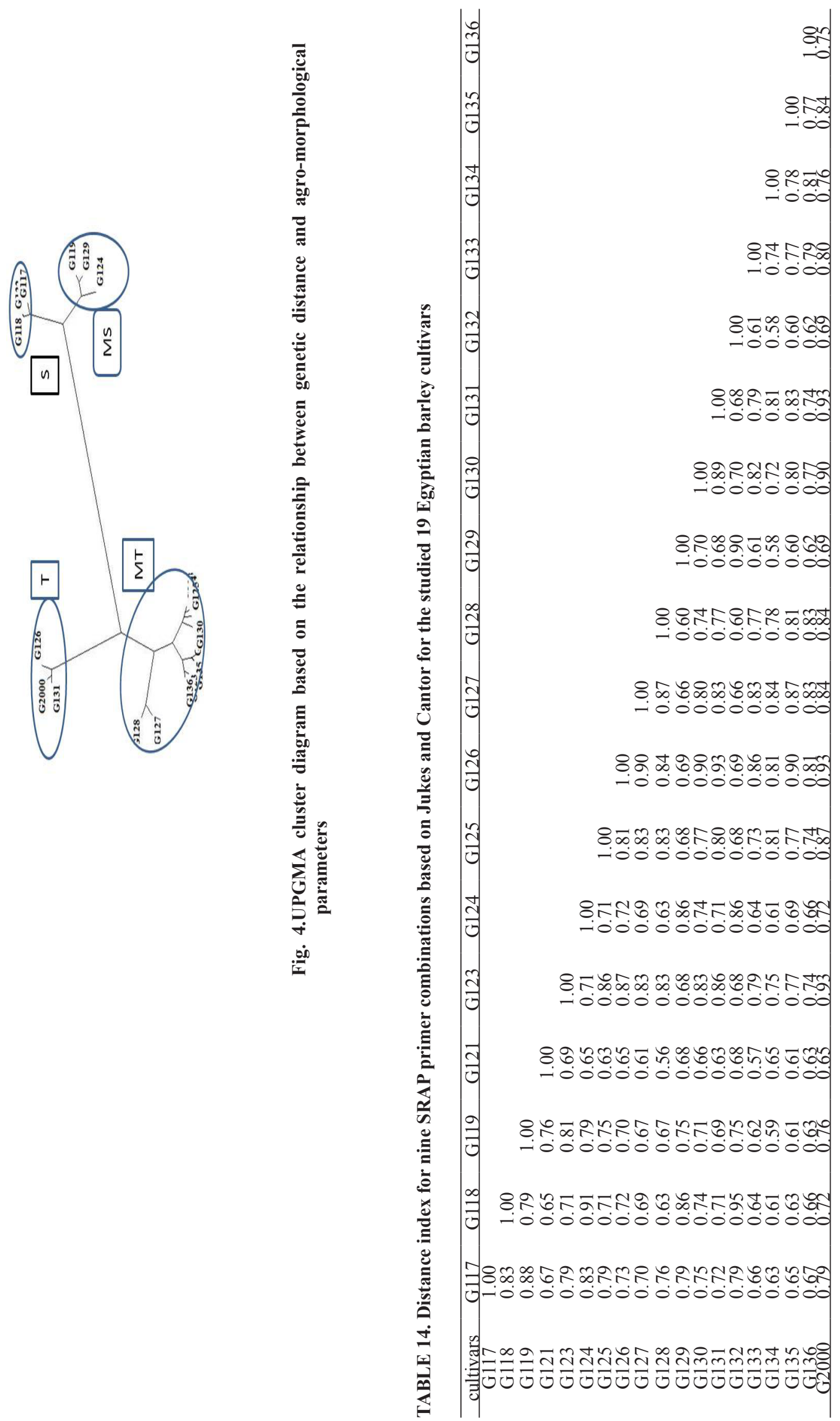


\section{References}

Abu-El-Lail, F.F.B, Hamam, K.A., Kheiralla, K.A. and El-Hifny, M.Z (2016) Evaluation of twenty barley genotypes for drought tolerance under sandy clay soil. Egypt. J. Agron. 38,173-187.

Anderson, J. A., Churchill, G. A., Autrique,,J. E., Tanksley, S. D and Sorrells, M. E. (1993) Optimizing parental selection for genetic linkage maps. Genome. 36, 181-186.

Black, C.A., Evans, D.D., White, J. L., Ensminger, L. E., and Clark, F. E. (1965) Methods of Soil Analysis. Part 2. Agron. Monogr. 9. Wisconsin, USA: American Society of Agronomy, Madison.

Ceccarelli, S. (1987) Yield potential and drought tolerance of segregation populations of barley in contrasting environments. Euphytica. 36,265-273.

Chalak, A. Lamis, Rim, B. Mzid, Wissam, A. Rizk, Haytham, A. Hmedeh, Rabih, C. Kabalan, Joelle, C. Breidy, Bariaa,C. Hamadeh, Hassan, D. Machlab, He'le'ne, A. Rizk and Samih, A. Elhajj (2015) Performance of 50 Lebanese barley landraces (Hordeum vulgare L. subsp. vulgare) in two locations under rainfed conditions. Annals of Agricultural Science, 60, 325-334.

Dai, X., Yang, Y., Zhou, L., Ou, L., Liang, M., Li, W., Kang, G. and Chen, B (2012) Analysis of Indicaand Japonica-specific markers of Oryza sativa and their applications. Plant Systematics and Evolution, 298, 287-296.

Dizkirici, A., Elif, K., Güren H., and Hikmet, B. (2010) Barley germplasms developed for scald disease resistance exhibited a high level of genetic diversity based on SRAP markers. Turkish Journal of Biology, 34, 271-279.

Dorostkar, S., Paknyiat, H., Kordshooli, M.A., Ghorbani, R., Aliakbari, Sobhanian, N. and Valiloo, R. (2016) Evaluation of several drought tolerance criteria in cultivated varieties of barley (Hordeum vulgare L.) and their relationships with yield reduction. Science Research, 4, 26-32.

Doyle, J.J. and Doyle, J.L. (1990).A rapid DNA isolation procedure for small quantities of fresh leaf tissue. Focus, 12, 13-15.

El-Madidi, S., Diani, Z. and Aameur, F.B. (2005) Variation of agro-morphological characters in Moroccan barley landraces under near optimal and drought conditions. Genetic Resources and Crop Evolution. Kluwer Academic Publishers, Dordrecht, Netherlands: 52 , 831-838.
El-Seidy, E.H. (1997) Estimation of genetic effects for earliness and some agronomic traits in barley under water stress and non-stress condition. Annals. of Agric. Sci., Zagazig Univ., Egypt, 35, 1147-1164

Esposito, MA, Martin, EA, Cravero, VP, Cointry, E (2007) Characterization of pea accessions by SRAP's markers. Sci. Hort. 113, 329-335.

Farshadfar, E. and Sutka, J. (2003) Screening drought tolerance criteria in maize. Acta Agronomica Hungarica. 50, 411-416.

Fatemeh Sefatgol and Hamidreza Ganjali (2017) Evaluation of drought stress tolerance in advanced barley cultivars in Sistan region. Biosci. Biotech. Res. Comm. 10, 276-286.

Forster, B. P., Ellis, R. P., Moir, J., Talamè, V., Sanguineti, M. C., Tuberosa, R., This, D., TeulatMerah, B., Ahmed, I., Mariey, S. A., Bahri, H., El-Ouahabi, M., Zoumarou-Wallis, N., El-Fellah, M., Salem, M. B. (2004) Genotype and phenotype associations with drought tolerance in barley tested in North Africa. Annals of Applied Biology, 144, $157-160$

Golabadi, M., Arzani, A. and Maibody, S.A.M. (2006) Assessment of drought tolerance in segregating populations in durum wheat. Afr. J. Agric. Res. 1, 162-171.

Haddadin Maisa'a Farah (2015) Assessment of Drought Tolerant Barley. International Journal of Agriculture and Forestry, 5, 131-137

Haddadin, M., Abedl-Ghani, A., and Al-Majali, N. (2013) Response of barely varieties to drought stress imposed at different developmental stages. Jordan Journal of Agricultural Sciences, 4, 507523.

Hamam, K.A. and Salman, A.M.A. (2007) Evaluation of spring barley genotypes tolerance to drought stress and aphid infestation. Annals. Agric. Sci, Ain Shams Univ., Cairo, 52, 327-340.

Hammer Ø., D.A.T. Harper, P.D. Ryan and PAST (2001) Paleontological statistics software package for education and data analysis, Palaeontologia Electronica, 4, 1-9.

Hayes, R. B., Zhang, L., Yin, S., Swenberg, J. A., Xi, L., Wiencke, J., and Smith, M.T. (2000) Genotoxic markers among butadiene polymer workers in China. Carcinogenesis, 21, 55-62.

Jiang, S.K., Ma, H., Liu, J., He, J., Guo, Z.F., Chen, L.J., Zhong, M., Zhang, L.J., Wang, X.Y., Zhang,

J. Sus. Agric .Sci. 44, No.1 (2018) 
L. (2007) Genetic Diversity in Maize Inbred lines Revealed by SRAP Marker. Mol. Pl. Breed. 3, 412416.

Li, G. and Quiros, C.F. (2001) Sequence-related amplified polymorphism (SRAP) a new marker system based on a simple PCR reaction, its application to mapping and gene tagging in Brassica. Theor. Appl. Genet. 103, 455-461.

Li, G., Peter, B. E., McVetty, and Carlos F. Quiros (2013) SRAP Molecular Marker Technology in Plant Science. Chapter from the book Plant Breeding from Laboratories to Fields, 24-43

Liu, J.M., Wang, L., Geng, Y.P., Wang, Q.B., Luo, L.J., Zhong, Y. (2006) Genetic diversity and population structure of Lamiophlomis rotate (Lamiaceae), an endemic species of Qinghai-Tibet Plateau. Genetica. 128, 385-394.

Mariey, A. Samah and. Khedr, A. Rania (2017) Evaluation of some Egyptian barley cultivars under water stress conditions using drought tolerance indices and multivariate analysis. J. Sus. Agric. Sci. 43, 105-114.

Mariey, A. Samah , Khatab I.A. and Kumamaru, T. (2015) Molecular markers associated with resistance to leaf rust among some barley genotypes. Egypt. J. Agric. Res. 93,413-421.

Minitab (1996) Minitab for widows release 11.12. Cited http://www.cit. cornell. edu/site-licenses/ minitab.html.

Munns, R. and James R.A.( 2003) Screening methods for salinity tolerance: A case study with tetraploid wheat. Plant Soil, 253, 201-218

Nazari, L. and Pakniyat, H. (2010) Assessment of drought tolerance in barley genotypes. J. Appl. Sci. 10,151-156

Nei, M. and Li, W.H. (1979) Mathematical model for studying genetic variation in terms of restriction endonucleases. Proc. Natl. Acad. Sci., 76, 52695273

Piper, C. S. (1950) Soil and Plant Analysis. Australia: Adelaide University Hassel Press

Ranjbar, G. H. and Cheraghi, S.A.M. (2010) Yield comparison of some iranian barley genotypes in saline areas of karkhe river basin. World Applied Sciences Journal. 11, 223-227.

Rizza, F., Badeck, F. W., Cattivelli, L., Li, Destri, O., Di Fonzo, N. and Stanca, A. M. (2004) Use of a water stress index to identify barley genotypes adapted to rainfed and irrigated conditions. Crop Science, 44, 2127-2137.

Robinson, D., Handley, L.L., Scrimgeour, C.M., Gordon, D.C., Forster, B.P., Ellis, R.P. (2000) Using stable isotope natural abundances $\left(\ddot{a}^{15} \mathrm{~N}\right.$ and $\ddot{a}^{13} \mathrm{C}$ ) to integrate the stress responses of wild barley (Hordeum spontaneum C. Koch.) genotypes. Journal of Experimental Botany, 4, 117-129.

Samarah, H. (2005). Effects of drought stress on growth and yield of barley. Agronomy Sustainable and Development, 25, 145-149.

Samarah, H., Mullen, E. and Anderson, I. (2009) Soluble sugar contents, germination and vigor of soybean seeds in response to drought stress. Journal of New Seeds, 10, 63-73.

Sanchez, D., Garcia, J. and Antolin, M. (2002) Effects of soil drought and atmospheric humidity on yield, gas exchange, and stable carbon isotope composition of barley. Photosynthetica, 40, 415-421.

Shakhatreh, Y., Kafawin, O., Ceccarelli, S. and Saoub, H. (2001) Selection of barley Lines for Drought Tolerance in Low-Rainfall. Journal of Agronomy and Crop Sciencek, 186, 119-127.

Sharafi, S., Ghassemi-Golezani, K., Mohammadi, S., Lak, S. and Sorkhy B. (2014) Evaluation of barley genotypes (hordeum vulgar l.) by drought tolerance indices and multivariate analysis. J. bioSci. 21,109-122.

Singh Bhagat, A.K., Dhaka, M. K. and Satish, K. (2017) Evaluation of drought tolerance indices for selection of barley (Hordeum vulgare 1.) cultivars under different levels of irrigation. Int. J. Curr. Microbiol. App. Sci. 6, 624-632.

Singh, A.P. (2011) Genetic variability in two-rowed barley (Hordeum vulgare L.) Indian J. Sci. Res., 2, 22-23.

Snedecor, C.W. and Cochran, W.G. (1969) Statistical Methods (6th ed.). Iowa State Univ. Press, Ames, Iowa,USA.

Subhani, G., Abdullah M., Ahmad, J., Anwar J., Hussain M. and Mahmood A. (2015) Identification of drought tolerant genotypes of barley (Hordeum vulgare L.) through stress tolerance indices. J. of Animal and Plant Sci. 25, 686-692.

Yang P, Liu, X.J., Liu, X.C., Li J., Wang, X.W., He, S.P., Li, G., Yang,W.Y. and Feng, Z.Y. (2008) Genetic diversity analysis of the developed qingke 
(hull-less barley) varieties from the plateau regions of Sichuan province in China revealed by SRAP markers. Hereditas (Beijing), 30, 115-122.

Yang, P., Liu, X., Liu, X., Yang, W. and Feng, Z. (2010) Diversity analysis of the developed qingke (hull-less barley) cultivars representing different growing regions of the Qinghai-Tibet Plateau in China using sequence related amplified polymorphism (SRAP) markers. African Journal of Biotechnology, 9, 8530-8538.

Zaefizadeh, M. and Goliev, R. (2009)Diversity and relationships among durum wheat landraces (subconvars) by SRAP and phenotypic marker polymorphism. Research Journal of Biological Sciences, 8, 960-966
Zhao, C.X., Guo, L.Y., Jaleel, C.A., Shoa, H.B. and Yang, H.B. (2008) Prospect for dissecting plant adaptive molecular mechanisms to improve wheat cultivars in drought environments. International Journal of Agriculture and Biology, 331, 579-586.

(Received: $10 / 1 / 2018$; accepted: $5 / 3$ / 2018)

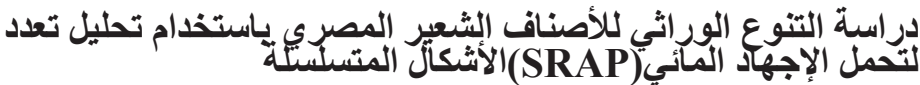

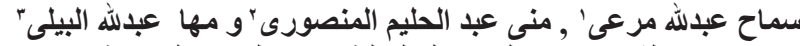

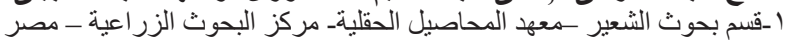

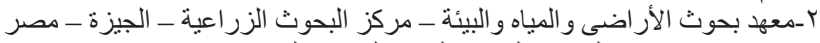

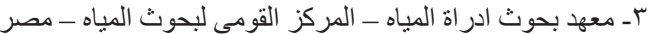

تم تقييم تجربتين حقليتين لدراسة تحليل التباين، متوسط الأداء، تحليل المكونات الرئيسية (PCA)

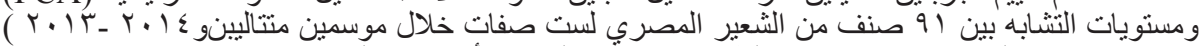

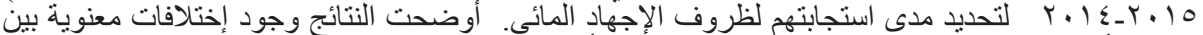

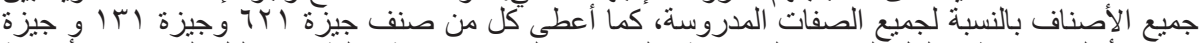

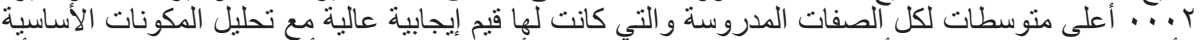

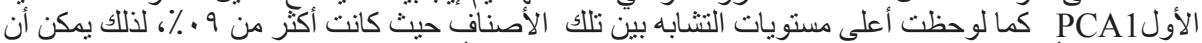

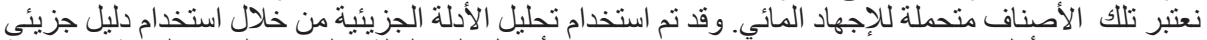

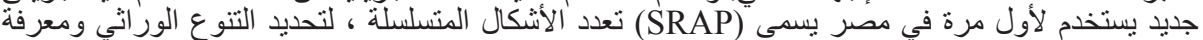

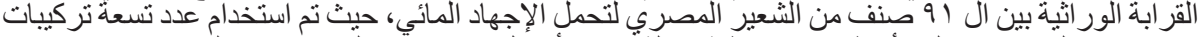

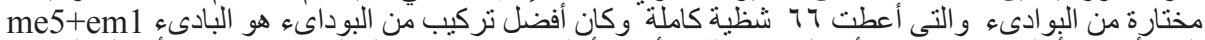

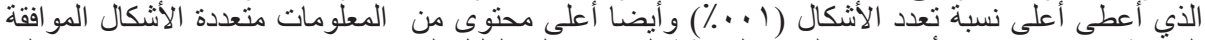

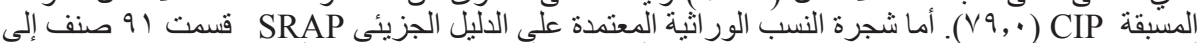

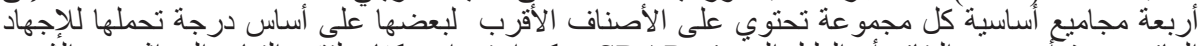

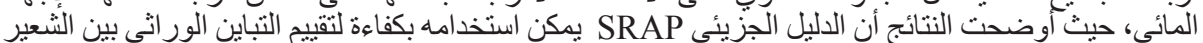

المصري وقدرثنه على تحمل الإجهاد المائي. 